\title{
The Degradation Potential of Some Fungal Isolates on Various Types of Waste Water
}

\author{
Esraa Salah Eldein Mohamed ${ }^{1}$ and Shami E. A. Bakhiet ${ }^{2}$ \\ ${ }^{I}$ Department of Microbiology \& Molecular Biology - Faculty of Science and Technology - Al-Neelain \\ University - Khartoum, SUDAN.
}

\begin{abstract}
The objective of this study was to determine the degradation activity of a number of isolated fungi (Aspergillus niger, Aspergillus fumigates and Mucor spp) against various types of wastewater. Waste water Samples were collected in sterile bottles from two places (CAPO Company and wastewater treatment plant in Haj Yousif), in October 2016. Metals and heavy metals were measured in wastewater samples before and after treatment by tested isolated fungi. Results showed increased reduction in Chemical oxygen demand (BOD) after treatment of CAPO CO. wastewater (96.23\%) rather than in Haj Yousif region (44.00 \%). Chemical oxygen demand (COD) exhibited more reduction after treatment of CAPO CO wastewater (95.7\%) rather than Haj Yousif region which increased by $18.81 \%$. Total suspended solids (TSS) reduced after treatment of CAPO CO. wastewater by $75 \%$ while in Haj Yousif region the reduction was $25 \%$. Moreover, no change was observed in Total dissolved Solids (TDS) after treatment of both CAPO CO. wastewater and Haj Yousif region $(0 \%)$. Similarly, no change was observed in NH3 content after treatment of CAPO CO. and Haj Yousif region ($36.66 \%)$. PO4/P, CL-, SO-24, $\mathrm{Fe}+++, \mathrm{Pb}+2$, and $\mathrm{Cr}+2$ were reduced after treatment of $\mathrm{CAPO} C \mathrm{CO}$ wastewater (\%49.23), While in Haj Yousif region were decreased as follows (-2.89, -11.12, -106.04, and -200) respectively. $\mathrm{Cu}+2$ quantity reduction was increased after treatment of CAPO CO wastewater (97\%) more than in Haj Yousif region (6.25 \%). Cd+2 in Haj Yousif region was increased (49.23\%), but in Capo CO wastewater was not detected $(N D)$. The present study demonstrated the efficiency of these tested microorganisms to degrade the heavy metals.
\end{abstract}

Keywords: Aspergillus fumigatus, Aspergillus niger, Mucor, suspended solids, Wastewater

\section{Introduction}

The Urban water and wastewater (hereafter called "water) infrastructure and technologies have a lifetime of 25- 100 years. Over this lifetime they have to function in systems that are increasingly subject to continuous and unpredictable changes [1].

Water demand and wastewater discharge may change as a result of faster economic and urban development, water use habits, technological progress and acceleration of climate change. As a result, treatment and transport networks have to cope with unexpected changes in capacity affecting their operational efficiency and effectiveness [2].

In addition, the introduction of sustainable urban water management sets new ambitions for water infrastructure and quality of treatment, including the recovery and reuse of water, nutrients and organics [3]. This leads to changing requirement for collection and transport networks and treatment performance [4].

The characteristics of wastewater depend firstly on the quality of the water supply, secondly on the type of distribution net for both drinking water and the grey wastewater (leaching from piping, chemical and biological processes in the biofilm on the piping walls) and thirdly from the activities in the household. The compounds present in the water vary from source to source, where the lifestyles, customs, installations and use of chemical household products will be of importance. The composition will vary significantly in terms of both place and time due to the variations in water consumption in relation to the discharged amounts of substances. Furthermore, there could be chemical and biological degradation of the chemical compounds, within the transportation network and during storage [5].

Municipal wastewater is mainly comprised of water $(99.9 \%)$ together with relatively small concentrations of suspended and dissolved organic and inorganic solids. Among the organic substances present in sewage are carbohydrates, lignin, fats, soaps, synthetic detergents, proteins and their decomposition products, as well as various natural and synthetic organic chemicals from the process industries [6].

Table 1. Major Constituents of typical domestic wastewater [7]

\begin{tabular}{|c|c|c|c|}
\hline \multirow[t]{2}{*}{ Constituent } & \multicolumn{3}{|c|}{ Concentration, mg/l } \\
\hline & Strong & Medium & Weak \\
\hline Total solids & 1200 & 700 & 350 \\
\hline Dissolved solids (TDS) $^{1}$ & 850 & 500 & 250 \\
\hline Suspended solids & 350 & 200 & 100 \\
\hline
\end{tabular}




\begin{tabular}{|c|c|c|c|}
\hline Nitrogen (as N) & 85 & 40 & 20 \\
\hline Phosphorus (as P) & 20 & 10 & 6 \\
\hline Chloride $^{1}$ & 100 & 50 & 30 \\
\hline Alkalinity (as $\mathrm{CaCO}_{3}$ ) & 200 & 100 & 50 \\
\hline Grease & 150 & 100 & 50 \\
\hline $\mathrm{BOD}_{5}{ }^{2}$ & 300 & 200 & 100 \\
\hline
\end{tabular}

${ }^{1}$ The amounts of TDS and chloride should be increased by the concentrations of these constituents in the carriage water.

${ }^{2} \mathrm{BOD}_{5}$ is the biochemical oxygen demand at $20{ }^{\circ} \mathrm{C}$ for 5 days and is a measure of the biodegradable organic matter in the wastewater.

Fungi have been utilized for removal of eutrophication agents and bioremediation of metal contaminated waste streams [8], [9]. There is an interest in the use of microorganisms for the removal of nitrogen, phosphorus, and metals from commercial and municipal waste [10]. Aspergillus niger, Aspergillus fumigates and Mucor spp are used widely in biotechnology for many processes, including the production of antibiotics, enzymes, food products, industrial acids, and alcohol. Also they used as biodegradable agents to treat the wastewaters. The main objective of this study is to determine the degradation activity of number of isolated fungi against various types of wastewater.

\subsection{Study Area}

\section{Materials And Methods}

This study was conducted in CAPO company (Khartoum North), wastewater treatment plant (Haj Yousif region) and Microbiology Laboratory - Department of Microbiology and Molecular Biology- Faculty of Science and Technology - Al-Neelain University, Khartoum-Sudan during the period of October-November 2016.

2.2. Collection of wastewater samples

A treated wastewater and untreated wastewater were collected using sterile bottles $1 \mathrm{~L}$ capacity. The treated wastewater was collected under aseptic conditions according to [11].

\subsection{Isolation of test microorganisms}

Soil sample ( $10 \mathrm{~g})$ were collected from agriculture area of Al-Nozha town in sterile plastic bag. An amount of $1 \mathrm{~g}$ of soil sample was taken, placed in test tube containing pre-sterilized $10 \mathrm{ml}$ distilled water to make a dilution of $10^{-1}$. The water suspension was diluted (tenfold) by transfer $1 \mathrm{ml}$ of each tubes to another one contain $9 \mathrm{ml}$ sterile distilled water consecutively. An amount of $1 \mathrm{ml}$ of dilution $10^{-1}$, and $10^{-2}$ were transferred to Petri dishes containing $20 \mathrm{ml}$ solidified Sabouraud's dextrose agar (SDA) media. All plates were incubated at $28{ }^{\circ} \mathrm{C}$ for 5 days. After incubation period the microorganisms were identified macroscopically and microscopically [12].

2.4. Wastewater treatment

\subsubsection{Preliminary screening}

The collected wastewater samples were preliminary screened by measuring; $\mathrm{pH}, \mathrm{BOD}, \mathrm{TSS}, \mathrm{COD}, \mathrm{TDS}, \mathrm{NH}_{3}{ }^{+1}$, $\mathrm{NO}_{3}^{-}, \mathrm{SO}_{4}^{-2}, \mathrm{CL}^{-}, \mathrm{PO}_{4}^{-2}, \mathrm{~Pb}^{-2}, \mathrm{Cu}^{+2}, \mathrm{Zn}^{+2}, \mathrm{Cr}^{+2}, \mathrm{Fe}^{+3}, \mathrm{Cd}^{+2}$.

\subsubsection{Biodegradation}

Sabouraud's dextrose agar (SDA) and Potato dextrose agar (PDA) media were prepared according the instructions of manufacturer (HiMedia, India), sterilized and poured in plates after added rose Bengal. After medium solidified, it was inoculated by soil suspension, and incubated in $30{ }^{\circ} \mathrm{C}$ for 72 hrs. After 3 days, inoculated plates were tested macroscopically and microscopically for fungal growth. Subculture made for pure growth and incubated again in new media in $30^{\circ} \mathrm{C}$ for another $72 \mathrm{hrs}$. The wastewater was treated by isolated fungi and incubated at $30{ }^{\circ} \mathrm{C}$ for $72 \mathrm{hrs}$. After incubation time, total elements were measured. Results were recorded before and after treatment [12].

\subsection{Isolation of test microorganisms}

\section{Results And Discussion}

Aspergillus niger was isolated and appeared as black powdery cottony colonies on SDA medium while it was appeared as smooth and generally colorless conidiophores and had conspicuous ridges or spines spores which not arranged in rows. Aspergillus fumigatus isolated and appeared as the surface growth is velvety, downy or powdery, showing various shades of green, most commonly a blue-green to a grey-green with a narrow white border. Microscopically, it showed typical columnar, uniseriate conidial heads. Conidiophores are short, smooth-walled and have conical shaped terminal vesicles, which support a single row of phialides on the upper two thirds of the vesicle. Mucor appeared Colonies are fluffy and gray, browning with time. The reverse is white or light-colored. Microscopic morphologically of Mucor; sporangiophores are often branched and rudimentary, small rhizoids are remote from the base of the sporangiophore (Figure, 1).

DOI: $10.9790 / 2402-1106037376 \quad$ www.iosrjournals.org $\quad 74 \mid$ Page




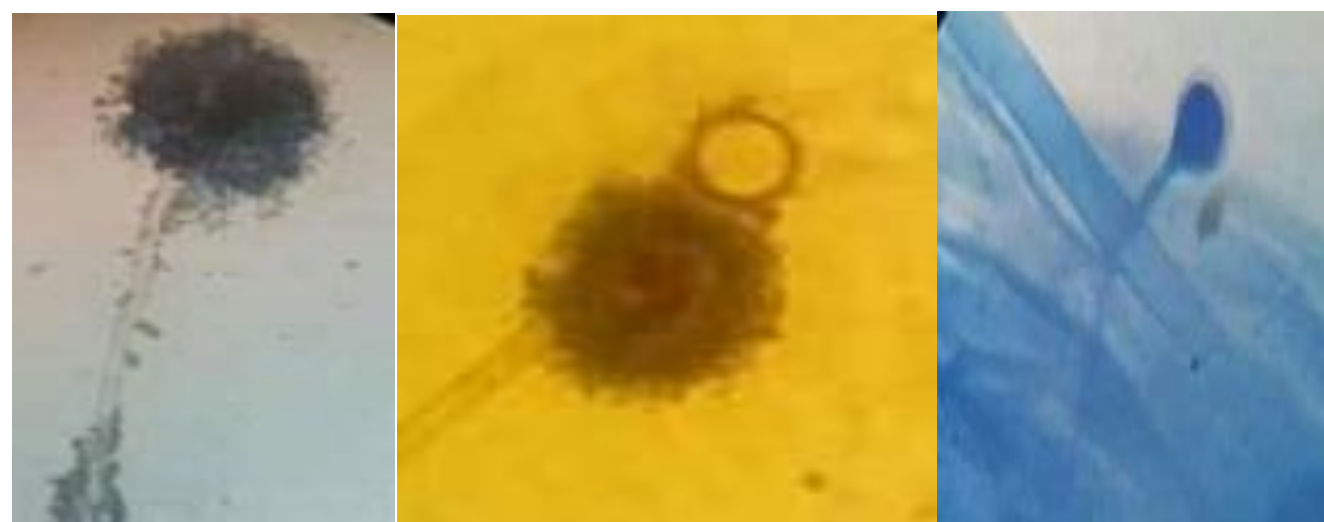

Figure 1. The microscopical appearance of A) Aspergillus niger B) Aspergillus fumigatus C) Mucor species.

\subsection{Treatment}

As can be seen in table 2, the $\mathrm{pH}$ value was increased by 1 unit after treatment of CAPO Company wastewater, but in Haj Yousif region it did not express any change. BOD increased after treatment of CAPO Co wastewater $(96.23 \%)$ rather than Haj Yousif region $(44.00 \%)$. COD increased after treatment of CAPO Co wastewater $(95.7 \%)$ rather than Haj Yousif region was increased $(18.81 \%)$. TSS reduced after treatment of CAPO Co wastewater (75 \%) but in Haj Yousif region was reduced to $(25 \%)$. TDS not changed after treatment in both regions CAPO Co wastewater and Haj Yousif region. $\mathrm{NH}_{3}$ after treatment of CAPO Co wastewater not changed, but in Haj Yousif region was increased $(-36.66 \%)$. $\left(\mathrm{PO}_{4} / \mathrm{P}, \mathrm{CL}^{-}, \mathrm{SO}^{-2}{ }_{4}, \mathrm{Fe}^{+++}, \mathrm{Pb}^{+2}\right.$, and $\left.\mathrm{Cr}^{+2}\right)$ reduced after treatment of CAPO Co wastewater $(49.23 \%)$, but in Haj Yousif region $\left(\mathrm{PO}_{4} / \mathrm{P}, \mathrm{SO}_{4}^{-2}, \mathrm{~Pb}^{+2}, \mathrm{Cr}^{+2}\right)$ was decreased as followed $(-2.89,-11.12,-106.04$, and $-200 \%)$ respectively. $\mathrm{Cu}^{+2}$ increase after treatment of CAPO Co wastewater $(97 \%)$ more than in Haj Yousif region was increased $(6.25 \%) . \mathrm{Cd}^{+2}$ in Haj Yousif region was increased (49.23\%), but in CAPO. Co wastewater not detected (ND). Similar results were obtained by Sanyal and co-warkers [13], who was observed that in the presence of the Fusarium oxysporum, metal carbonates are formed by the reaction of the heavy metal ions with carbon dioxide produced by the fungus during metabolism, thus providing a completely biological method for production of crystals of metal carbonates.

The major advantage of this approach is that the reaction leads to detoxification of the aqueous solution and could have immense potential for bioremediation of heavy metals. Under conditions of their study, the metal ions were not observed to be toxic to the fungus, which readily grows after exposure to the metal ions. Also the present study was in agreement with Sarabjeet Singh and Dinesh, [14] who stated that the biomass of Aspergillus niger, Penicillium chrysogenum, Rhizopus nigricans, Ascophyllum nodosum, Sargassum natans, Chlorella fusca, Oscillatoria anguistissima, Bacillus firmus and Streptomyces sp. have highest metal adsorption capacities ranging from 5 to $641 \mathrm{mg} / \mathrm{g}$ mainly for $\mathrm{Pb}, \mathrm{Zn}, \mathrm{Cd}, \mathrm{Cr}, \mathrm{Cu}$ and $\mathrm{Ni}$. Biomass generated as a by-product of fermentative processes offers great potential for adopting an economical metal-recovery system.

The findings of this study were in agreement with that's obtained by Sag et al., [15] and Goyal et al., [16] whom reported that there appeared to be a significant inhibition in the adsorption of Fe (III) by Saccharomyces equisimilis, Saccharomyces cerevisiae and A. niger in the presence of increasing concentration of $\mathrm{Cr}$ (VI) ion. The maximum amount of adsorbed Fe (III) ion per unit weight of dried biomass, at $50 \mathrm{mg} / \mathrm{l} \mathrm{Fe}$ (III), by Saccharomyces equisimilis, Saccharomyces cerevisiae and A. niger was measured as 19.73, 16.9 and $22.27 \mathrm{mg} / \mathrm{g}$, respectively. When $50 \mathrm{mg} / \mathrm{l} \mathrm{Cr}$ (VI) was added to the biosorption media containing $50 \mathrm{mg} / \mathrm{l} \mathrm{Fe}$ (III), the adsorption of Fe (III) by S. equisimilis, S.cerevisiae and A. niger after $24 \mathrm{~h}$ decreased to 15.33, 12.1 and 20 $\mathrm{mg} / \mathrm{g}$, respectively. However, higher concentrations of both the metal ions seemed to be better tolerated by the fungus than the bacteria and yeasts. The present study was in disagreement with the Yan and Viraraghavan, [17] who observed that biosorption column of Mucro rouxii biomass was able to remove metal ions $(\mathrm{Pb}, \mathrm{Cd}, \mathrm{Ni}$, and $\mathrm{Zn}$ ) not only from single-component metal solutions but also from multi-component metal solutions. The metal removal capacities of the biomass for $\mathrm{Pb}, \mathrm{Cd}, \mathrm{Ni}$, and $\mathrm{Zn}$ were 4.06, 3.76, 0.36, and $1.36 \mathrm{mg} / \mathrm{g}$ respectively. For a multi-component metal solution containing $\mathrm{Cd}, \mathrm{Ni}$, and $\mathrm{Zn}$ were $0.36,0.31$ and $0.40 \mathrm{mg} / \mathrm{g}$ respectively. Also the results were in agreement with Narsi and Garima, [18] who reported that the heavy metal removal capacity of fungal biomass is determined by several factors with $\mathrm{pH}$ being the most important variable. Pretreatment methods have usually shown an increase in the metal sorption capacity for the variety of fungal species. Fungal biomass can be regenerated relatively easily and used again. Most significantly, the metal removal capacity of fungal biomass is as good as or better than other conventional adsorbents. The biosorption-based processes can be considered as a replacement of an existing metal-removal technology or can also be used as a polishing unit for an existing treatment facility. 
Table 2. Measurement of elements in wastewater collected from CAPO Co and Haj Yousif region before and after treatment by test fungal species.

\begin{tabular}{|l|l|l|l|l|l|l|l|}
\hline \multicolumn{5}{|c|}{ CAPO company } & \multicolumn{3}{c|}{ Haj Yousif region } \\
\hline Test & Unit & INLET & OUTET & Reduction \% & INLET & OUTLET & Reduction \% \\
\hline $\mathrm{pH}$ & $\mathrm{pH}$ unit & 6.0 & 7.0 & +1 & 7.0 & 7.00 & 0 \\
\hline $\mathrm{BOD}$ & $\mathrm{Mg} / 1$ & 612.5 & 22.8 & 96.23 & 480 & 268.80 & 44 \\
\hline $\mathrm{DO}$ & $\mathrm{Mg} / 1$ & - & - & $\mathrm{ND}$ & - & 0.9 & $\mathrm{ND}$ \\
\hline $\mathrm{COD}$ & $\mathrm{Mg} / 1$ & 2400 & 103 & 95.7 & 331.1 & 268.8 & 18.81 \\
\hline $\mathrm{TSS}$ & $\mathrm{Mg} / 1$ & 420 & 60 & 75.00 & 160 & 120 & 25.00 \\
\hline $\mathrm{TDS}$ & $\mathrm{Mg} / 1$ & - & 1860 & $\mathrm{ND}$ & 660 & 660 & 0 \\
\hline $\mathrm{NH}_{3}$ & $\mathrm{Mg} / 1$ & 22.4 & 22.4 & 0 & 16.8 & 22.96 & -36.66 \\
\hline $\mathrm{PO}_{4} / \mathrm{P}$ & $\mathrm{Mg} / 1$ & 3.8415 & 1.95 & 49.23 & 3.45 & 3.55 & -2.89 \\
\hline $\mathrm{Cl}$ & $\mathrm{Mg} / 1$ & 764.124 & 387.88 & 49.23 & 79.97 & 75.98 & 4.98 \\
\hline $\mathrm{SO} 4$ & $\mathrm{Ppm}$ & 591.9062 & 300.46 & 49.23 & 74.08 & 82.32 & -11.12 \\
\hline $\mathrm{Fe}$ & $\mathrm{Ppm}$ & 0.11426 & 0.058 & 49.23 & 1.006 & 0.89 & 11.53 \\
\hline $\mathrm{Pb}$ & $\mathrm{Ppm}$ & 0.30338 & 0.154 & 49.23 & 0.0794 & 0.1636 & -106.04 \\
\hline $\mathrm{Cr}$ & $\mathrm{Ppm}$ & 0.09456 & 0.048 & 49.23 & 0.0098 & 0.0294 & -200.00 \\
\hline $\mathrm{Cu}$ & $\mathrm{Ppm}$ & 0.23443 & 0.119 & 97.0 & 0.112 & 0.105 & 6.25 \\
\hline $\mathrm{Cd}$ & $\mathrm{Ppm}$ & - & - & $\mathrm{ND}$ & 0.02167 & 0.011 & 49.23 \\
\hline
\end{tabular}

$\mathrm{ND} \equiv$ not detected

\section{Conclusion}

The isolated microorganisms have an ability to degrade metals and heavy metals present in wastewater which might lead to make water fit to use for other purposes (swimming, irrigation, washing) rather than drinking.

\section{References}

[1]. P Gober, D White, and R Quay, Socio-hydrology for an uncertain future, with examples from the USA and Canada. Model fusion, Geophysical Society, London (forthcoming), 2013

[2]. S Panebianco, and C Pahl-Wostl, Modelling socio-technical transformations in wastewater treatment - A methodological proposal. Technovation, 2, 2006, 1090-1100.

[3]. RR Brown, and MA Farrelly, Delivering sustainable urban water management: a review of the hurdles we face. Water Sci. Technol, $59(5), 2009,839-846$.

[4]. G Daigger, Integrating Water land Resource Management (Nelson, Ed I. WA press, London, 2012).

[5]. PJ Roeleveld, and MC van Loosdrecht, Experience with guidelines for wastewater characterization in The Netherlands. Wat. Sci. Tech. 45(6), 2002, 77-87.

[6]. MK de Kreuk, C Picioreanu, M Hosseini, JB Xavier, and MC van Loosdrecht, Kinetic model of a granular sludge SBR - influences on nutrient removal. Biotech. Bioeng. 97(4), 2007, 801-815.

[7]. UN Department of Technical Cooperation for Development, The use of non-conventional water resources in developing countries. Natural Water Resources Series No. 14. United Nations DTCD, New York, 1985.

[8]. MN Akthar, and PM Mohan, Bioremediation of toxic metal ions from polluted lake waters and industrial effluents by fungal biosorbent. Current Science, 69, 1995, 1028-1030

[9]. P Bosshard, R Bachofen, and H Brandl, Metal leaching of fly ash from municipal waste incineration by Aspergillus niger. Environ. Sci. Technol. 30, 1996, 3066-3070.

[10]. MB Cassidy, H Lee, and JT Trevors, Environmental applications of immobilized microbial cells: A review. Journal of Industrial Microbiology, 16(2), 1996, 79-101.

[11]. A Elshayeb, In Vitro tests for bacteriophages against Sudanese Bacteria species: Bacteriological Studies and Protein Profiles of Escherichia coli, Staphylococcus aureus and their phages. (Lap Lambert Academic Publishing, Germany, 2010) ISBN139783838386034.

[12]. $\quad$ KR Aneja, Experiments in Microbiology, Plant Pathology and Biotechnology. 4th Ed., (New Delhi, 2005). 248-254.

[13]. V Sanyal, D Rautaray, V Bansal, A Ahmad, M Sastry, Heavy metal remediation by a fungus as a means of production of lead and cadmium carbonate crystals. Langmuir, 21(16), 2005, 7220-7224.

[14]. A Sarabjeet Singh, and G Dinesh, Review: Microbial and plant derived biomass for removal of heavy metals from wastewater. Biores. Technol, 98, 2007, 2243-2257.

[15]. Y Sag, T Kutsal, U Acikel, and ZA Aksu, Comparative study for the simultaneous biosorption of Cr (VI) and Fe (III) on C. vulgaris and $R$. arrhizus: application of the competitive adsorption models. Process Biochem, 33, 1998, 273-281.

[16]. N Goyal, SC Jain, and U Banerjee, Comparative studies on the microbial adsorption of heavy metals. Advances in Environmental Research, 7, 2003, 311-319.

[17]. G Yan, and T Viraraghavan, Heavy metal removal in a biosorption column by immobilized Mucor rouxii biomass. Biores. Technol, $78,2001,243-249.522$.

[18]. R Narsi, and Garima, Fungus-An alternative for bioremediation of heavy metal containing wastewater: A review. J. Sci. Ind. Res, 64, 2005, 93-100. 